\title{
The Posibilities Using of Bee Pollen Powder on Breeding Japanese Quail Rations: I. Effect on Performance and Hatching Egg Quality Characteristics
}

\author{
Yuksel Akin (Corresponding author) \\ Graduate Education, Animal Science, Usak University \\ PO box 64100, Usak, Turkey \\ E-mail: yuksel.akin@usak.edu.tr \\ Mehmet Fatih Celen \\ Faculty of Agriculture, Animal Science, Usak University \\ PO box 64100, Usak, Turkey \\ E-mail: faith.celen@usak.edu.tr
}

University of Usak Scientific Research Projects Coordination Unit (USRP) Project 2017 / TP-030 finance the research.

\begin{abstract}
In this study, it was aimed to determine the posibilities use of supplementing breeder diets with different level concentrations (C: 0, BPP1: 1, BPP5: 5, BPP10: 10, and BPP20: $20 \mathrm{~g} / \mathrm{kg}$ feed) of the bee pollen powder (BPP) effect on performance and hatching egg quality characteristics in Japanese quails. The experimental animals consisted of 9-week-old Japanese quails, including 105 females and 45 males, and the experiment continued for six weeks. The results showed higher than control group significant effects of the (BPP) supplementation to quail diets on yolk level $(\mathrm{P}<0.01)$, shell thickness, and Haugh unit $(\mathrm{P}<0.05)$, but not significant effects as raise or decrease were observed on live gain, consumption feed, feed conversion ratio, egg weight, shape index, yolk index, white index, and shell weight $(\mathrm{P}>0.05)$. Taken together, these results can be recommended BPP supplementation of quail diets.
\end{abstract}

Keywords: Bee pollen, feeding, hatching egg quality, Japanese quails (Coturnix coturnix japonica).

DOI: $10.7176 / \mathrm{JSTR} / 6-13-04$

\section{Introduction}

Poultry meat and egg are animal protein sources that have an important effect on nourishment and antibiotics have been used as growth factors in poultry for many years because of their growth enhancement effects in poultry. However, antibiotics, as well as the pathogenic microorganisms residing in the digestive tract of animals, prevent the proliferation of beneficial microorganisms. Turkey and European Union countries, the long-term use of antibiotics as feed additives has been banned against the risk of creating microorganism strains with high antibiotic resistance in animals as well as in humans consuming these products (Jensen, 1998; Anonim, 2002; Anonymous, 2003; Anonim, 2005; Nollet, 2005; Özen et al., 2005, Anonim, 2006). As a result of these developments; prebiotics, probiotics, essential oils, humates, and medicinal and aromatic plants are used as alternative feed additives against antibiotics because they prevent sub-clinical infections, encourage growth and are not harmful, but rather benefical, to human health (Ball, 2000; Bach Knudsen, 2001; Yalçın et al., 2002; Güçlü, 2003; Güler et al., 2005; Islam et al., 2005). Bee pollen, which can be used as an alternative to antibiotics, is defined as the flower powder collected by bees.

The pollen values of the plant species and varieties from which the pollen is collected are increasing in terms of human health (Doğaroğlu, 2008). For example, acer (Acer spp.), walnut (Juglans regia), mulberry (Morus spp.), ash (Fraxinus spp.), hazelnut (Corylus spp.), birch (Betula spp.), elm (Ulmus spp.), chestnut (Castanea sativa), alder (Alnus spp.), willow (Salix spp.), and boxwood (Buxus spp.) are important tree species from which the pollen is collected (Sönmez and Altan, 1992). Bee pollen is rich

24 | P a g e

www.iiste.org 
in proteins, carbohydrates and lipids, as well as the major and minor elements found in plant tissues. In addition, it contains organic substances, such as amino acids, nucleic acids, enzymes, vitamins, minerals and hormones (Stanley and Linskens, 1985; Genç, 1993; Orzaez et al., 2002; Karataş and Şerbetçi, 2008).

Bee pollen and pollen products contain significant amounts of polyphenol compounds with antioxidant potential. They are used in alternative medicine, treatment of some diseases and nourishment, because they have several properties, such as antimicrobial, antibacterial, anti-allergic etc., can regulate brain functions and metabolism, and are effective against stress and psychological problems (Sorkun, 1987; Genç, 1993; Schmidt, 1997; Çakmak, 2001; Basim et al., 2006; Medeiros et al., 2008). In this study, we aimed to investigate the effects of nutrient-rich bee pollen on performans and hatching egg quality characteristics in Japanese quails (Coturnix coturnix japonica).

\section{Materials and Methods}

\subsection{Research Design}

In this study, 150 (105 female and 45 male) Japanese quails (Coturnix coturnix japonica) were used at 9 weeks of age. The experiment was composed of five groups (including a control group), which were feed diets supplemented with bee pollen powder (BPP) at different concentrations (C: 0, BPP1: 1, BPP5: 5, BPP10: 10, and BPP20: $20 \mathrm{~g} / \mathrm{kg}$ feed). Each group, had three replicates, with each replicate comprising 10 ( 7 female and 3 male) animals. The experiment was conducted according to protocol number (2018/01-01) of the University Committee on Animal Use.

\subsection{Research Instruments and Procedures}

The feed for control group was obtained from a private commercial company that sells quail feeds. The feeds of the pollen groups were constituted by supplementing their basal diet with the Uşak-region bee pollen, which was obtained from a company that sells bee products. In this study, the five-story threecompartment group cages (width-97 cm, depth- $63 \mathrm{~cm}$, height-189 cm) with an automatic drinker system were used. During the experimental period, 8-h of darkness and 16-h of light were applied. Feed and water were provided ad-libitum to the experimental animals that were subjected to group feeding. In the preparation of the experimental ration, the 30 -and $0.1-\mathrm{kg}$ weighing scale were used. In order to determine the internal quality characteristics of eggs, the white and yellow diameters, and white length were measured using a digital caliper, and the white and yellow heights were determined using a 1/100 mm sensitive tripod micrometer. In order to determine egg shell thickness, a micrometer was used, and to evaluate its yellow color, a DSM scale (1-16) was used. The present study was carried out at Uşak University, Faculty of Agriculture and Natural Sciences, Animal Husbandry Experiment Unit (geographical coordinates: $38^{\circ o}-40^{\prime \prime}-05.7^{\prime \prime \prime}-\mathrm{N}, 29^{\circ o}-19^{\prime \prime}-40.0^{\prime \prime \prime}-\mathrm{E}$ ). The daily egg yields of quails were recorded from two weeks before the beginning of the experiment. At the end of the second week, the animals of similar live weights were randomly distributed to the experimental groups according to the design of the experiment. At the beginning and end of the experiment, the quails were weighed to determine their live weights (LW) and live gains (LG).

During the experiment, an equal amount of pre-weighed feed was given to each replicate, and their average weekly and daily feed consumptions were determined by subtracting the residual feed collected at the end of the week from the total feed given during the week. The weekly feed consumption ratio (FCR), was calculated by using the formula $\mathrm{FCR}=\mathrm{kg}$ feed $/ \mathrm{kg}$ egg in order to determine the amount of feed consumed to obtain animal products. The quails were fed a basal diet supplemented with 1, 5, 10, and $20 \mathrm{~g} / \mathrm{kg} \mathrm{BPP,} \mathrm{whereas} \mathrm{the} \mathrm{quails} \mathrm{in} \mathrm{the} \mathrm{control} \mathrm{groups} \mathrm{were} \mathrm{fed} \mathrm{with}$ only the basal diet. The diets were formulated according to the National Research Council (NRC, 2001). The ingredients and chemical analyses of the diets fed to the Japanese quails used in this experiment are given in Table 1.

Throughout the trial, the daily egg yields and weights of the animals were recorded once a week and the internal (such as yellow color of scale, white and yellow heights, and white and yellow diameters) and external quality characteristics (such as weight, width-length, shell weight, shell thickness) of 10 eggs (50 in total) from each group were determined every two weeks. The statistical analysis of the data was performed with one-way analysis of varience (ANOVA) using the SPSS package program, and the treatment group averages were compared using Duncan's multiple comparison test (Düzgüneş et al., 1987). For the values determined as percentages, transformations were made to perform variance homogeneity tests. The data obtained at the end of the study were analyzed by the General Linear Model (GLM) method using the SPSS (ver: 16) package program.

25 | $P$ a g e

www.iiste.org 
Formula:

$Y_{i j}=\mu+P_{i}+\Sigma_{i}$,

$Y_{i j}=$ Observation value,

$\mu=$ Population average,

$P_{i}=$ Effect of “ $i$,st" pollen contribution group,

$\Sigma_{i j=}$ Trial error

Table 1. Ingredients and chemical analyses of the diets

\begin{tabular}{|l|c|}
\hline Feed Materials & $\mathbf{g ~ k g}^{-1}$ as fed \\
\hline Wheat & 300 \\
\hline Maize & 350 \\
\hline Soybean meal & 165 \\
\hline Sunflower seed meal & 86 \\
\hline Wheat bran & 30 \\
\hline Calcium carbonate & 43 \\
\hline Meat-bone meal & 3 \\
\hline Vegatable oil & 15 \\
\hline Monocalcium phosphate & 1,5 \\
\hline Vitamin* & 2,5 \\
\hline Mineral** & 1,5 \\
\hline Salt & 2,5 \\
\hline Total & 190 \\
\hline Metabolizable energy $(\mathrm{kcal} / \mathrm{kg})$ & 2950 \\
\hline Crude protein $\left(\mathrm{g} \mathrm{kg}{ }^{-1}\right.$ as fed) & 190 \\
\hline
\end{tabular}

*Each $\mathrm{kg}$ of vitamin mix. contains; $15.000 .000 \mathrm{mg}$ vit. A, 3.000.000 mg vit. $D_{3,3} 30.00 \mathrm{mg}$ vit. E

**Each $\mathrm{kg}$ mineral mix. contains ; $60.000 \mathrm{mg} \mathrm{Mn,60.000} \mathrm{mg} \mathrm{Fe,} 50.000 \mathrm{mg} \mathrm{Zn,} 15.000 \mathrm{mg} \mathrm{Cu,250} \mathrm{mg} \mathrm{Co,850}$ mg I, $500 \mathrm{mg} \mathrm{Se}$.

\section{Results}

In this study; the supplementation of the basic diet with different concentrations of BPP had no significant effect on the live gain, feed consumption, feed conversion ratio, egg yields of the studied quails $(\mathrm{P}>0.05)$ (Table 2, 3, 4 and 5). 
International Journal of Scientific and Technological Research

ISSN 2422-8702 (Online), DOI: 10.7176/JSTR/6-13-04

Table 2. Mean live gains of male and female breeder quails ( $\mathrm{g} / \mathrm{bird}$ )

\begin{tabular}{|c|c|c|c|c|c|c|c|}
\hline \multicolumn{8}{|c|}{ GROUPS } \\
\hline & $\mathrm{C}$ & BPP1 & BPP5 & BPP10 & BPP20 & $\begin{array}{l}\text { Standard Error } \\
\text { of Mean (SEM) }\end{array}$ & $\begin{array}{c}\text { Significance } \\
\text { (SG) }\end{array}$ \\
\hline $\begin{array}{l}\text { Number of } \\
\text { quails for } \\
\text { each group }\end{array}$ & 9 & 9 & 9 & 9 & 9 & - & - \\
\hline $\begin{array}{l}\text { Male } \\
\text { beginning of } \\
\text { experiment }\end{array}$ & 179.13 & 183.46 & 180.80 & 179.68 & 182.98 & 2.693 & 0.983 \\
\hline $\begin{array}{l}\text { Ending of } \\
\text { experiment } \\
\text { (end of } 6^{\text {th }} \\
\text { weeks) }\end{array}$ & 185.41 & 189.12 & 190.87 & 190.38 & 189.15 & 2.807 & 0.979 \\
\hline $\begin{array}{l}\text { Number of } \\
\text { quails for } \\
\text { each group }\end{array}$ & 21 & 21 & 21 & 21 & 21 & - & - \\
\hline $\begin{array}{l}\text { Female } \\
\text { beginning of } \\
\text { experiment }\end{array}$ & 203.08 & 199.71 & 200.17 & 210.51 & 204.17 & 2.119 & 0.508 \\
\hline $\begin{array}{l}\text { Ending of } \\
\text { experiment } \\
\text { (end of } 6^{\text {th }} \\
\text { weeks) }\end{array}$ & 225.62 & 231.05 & 222.81 & 228.50 & 221.62 & 2.155 & 0.628 \\
\hline
\end{tabular}

Table 3. Daily average feed consumption of the experimental groups (g/ day / bird)

\begin{tabular}{|c|c|c|c|c|c|c|c|}
\hline \multicolumn{8}{|c|}{ GROUPS } \\
\hline WEEKS & C & BPP1 & BPP5 & BPP10 & BPP20 & SEM & SG \\
\hline 1. & 27.68 & 26.51 & 27.39 & 26.09 & 26.47 & 0.333 & 0.571 \\
\hline 2. & 23.42 & 24.14 & 25.07 & 25.01 & 24.45 & 0.356 & 0.635 \\
\hline 3. & 25.01 & 25.69 & 27.10 & 25.31 & 24.54 & 0.403 & 0.354 \\
\hline 4. & 24.54 & 26.47 & 25.24 & 24.36 & 24.94 & 0.508 & 0.765 \\
\hline 5. & 23.85 & 25.96 & 25.14 & 24.79 & 23.99 & 0.393 & 0.468 \\
\hline 6. & 24.18 & 25.49 & 25.18 & 24.77 & 23.98 & 0.296 & 0.489 \\
\hline
\end{tabular}


Table 4. Feed conversion ratio of experimental groups ( $\mathrm{kg}$ feed / $\mathrm{kg}$ egg)

\begin{tabular}{|c|c|c|c|c|c|c|c|}
\hline \multicolumn{9}{|c|}{ GROUPS } \\
\hline WEEKS & C & BPP1 & BPP5 & BPP10 & BPP20 & SEM & SG \\
\hline 1. & 4.10 & 3.24 & 3.90 & 3.50 & 3.26 & 0.166 & 0.398 \\
\hline 2. & 2.96 & 2.45 & 2.42 & 2.80 & 2.74 & 0.119 & 0.612 \\
\hline 3. & 2.62 & 2.35 & 2.43 & 2.66 & 2.69 & 0.086 & 0.721 \\
\hline 4. & 2.68 & 2.49 & 2.34 & 2.53 & 2.75 & 0.078 & 0.544 \\
\hline 5. & 2.80 & 2.23 & 2.26 & 2.46 & 2.58 & 0.084 & 0.153 \\
\hline 6. & 2.75 & 2.30 & 2.41 & 2.42 & 2.78 & 0.087 & 0.288 \\
\hline
\end{tabular}

Table 5. Average daily egg yields of the experimental groups (\%)

\begin{tabular}{|c|c|c|c|c|c|c|c|}
\hline \multicolumn{8}{|c|}{ GROUPS } \\
\hline WEEKS & C & BPP1 & BPP5 & BPP10 & BPP20 & SEM & SG \\
\hline 1. & 59.86 & 71.42 & 63.95 & 65.98 & 70.75 & 2.715 & 0.704 \\
\hline 2. & 69.38 & 81.63 & 83.68 & 73.47 & 72.79 & 3.448 & 0.701 \\
\hline 3. & 80.95 & 80.95 & 89.12 & 91.84 & 79.59 & 3.142 & 0.704 \\
\hline 4. & 75.51 & 85.03 & 83.67 & 75.51 & 72.79 & 2.837 & 0.624 \\
\hline 5. & 78.23 & 95.24 & 91.16 & 80.27 & 75.51 & 3.156 & 0.196 \\
\hline 6. & 72.79 & 85.03 & 82.99 & 79.59 & 70.07 & 2.834 & 0.427 \\
\hline
\end{tabular}

Among the internal and external quality characteristics of eggs, while the egg weight, shape index, white index, and shell weight values were not found statistically significant in all three measurements $(\mathrm{P}>0.05)$, the yellow color value was found to be significant in all measurements except for the first one $(\mathrm{P}<0.01)$. However, the yolk index value was statistically significant only in the first measurement $(\mathrm{P}<0.05)$. The Haugh unit was found to be statistically significant in the first two measurements $(\mathrm{P}<0.01$ ve $\mathrm{P}<0.05)$, but not in the final measurement $(\mathrm{P}>0.05)$. The egg shell thickness was found to be statistically significant at the end of the trial $(\mathrm{P}<0.01)$ (Table 6, 7 and 8). 
Table 6. First measurement internal and external quality characteristic of eggs ( $2^{\text {nd }}$ week $)$

\begin{tabular}{|c|c|c|c|c|c|c|c|}
\hline \multicolumn{8}{|c|}{ GROUPS } \\
\hline & $\mathrm{C}$ & BPP1 & BPP5 & BPP10 & ВРP20 & SEM & $\mathrm{SG}$ \\
\hline Egg weight & 11.84 & 12.49 & 11.72 & 12.02 & 11.92 & 0.121 & 0.308 \\
\hline $\begin{array}{l}\text { Yolk color } \\
\text { value }\end{array}$ & 7.90 & 8.80 & 8.90 & 8.70 & 8.50 & 0.148 & 0.224 \\
\hline Shape index & 77.46 & 78.76 & 77.68 & 78.43 & 77.67 & 0.335 & 0.708 \\
\hline Yolk index & $46.16^{\mathrm{c}}$ & $46.86^{b c}$ & $49.41^{\mathrm{a}}$ & $46.98^{b c}$ & $48.83^{\mathrm{ab}}$ & 0.363 & $0.013^{*}$ \\
\hline White index & 7.69 & 8.61 & 8.10 & 8.27 & 8.27 & 0.117 & 0.168 \\
\hline Haugh unit & $73.25^{\mathrm{c}}$ & $79.00^{\mathrm{a}}$ & $75.77^{\mathrm{bc}}$ & $76.57^{\mathrm{ab}}$ & $77.38^{\mathrm{ab}}$ & 0.470 & $0.001 * *$ \\
\hline Shell thickness & 0.197 & 0.197 & 0.19 & 0.194 & 0.189 & 0.001 & 0.295 \\
\hline Shell weight & 1.63 & 1.67 & 1.59 & 1.61 & 1.63 & 0.021 & 0.818 \\
\hline
\end{tabular}

$a, b, c:$ The difference between average values carrying different letters in the same order is statistically significant. (*): $P<0.05$, (**): $P<0.01$

Table 7. Second measurement internal and external quality characteristic of eggs $\left(4^{\text {th }}\right.$ week $)$

\begin{tabular}{|l|c|c|c|c|c|c|c|}
\hline \multicolumn{7}{|c|}{ GROUPS } \\
\hline & C & BPP1 & BPP5 & BPP10 & BPP20 & SEM & SG \\
\hline Egg weight & 12.40 & 12.60 & 12.84 & 12.95 & 12.51 & 0.146 & 0.765 \\
\hline Yolk color value & $7.70^{\mathrm{b}}$ & $9.40^{\mathrm{a}}$ & $9.10^{\mathrm{a}}$ & $9.60^{\mathrm{a}}$ & $9.50^{\mathrm{a}}$ & 0.174 & $0.001^{* *}$ \\
\hline Shape index & 78.28 & 78.67 & 7979 & 79.57 & 78.98 & 0.464 & 0.847 \\
\hline Yolk index & 46.30 & 45.35 & 4799 & 46.70 & 47.44 & 0.380 & 0.217 \\
\hline White index & 7.21 & 8.64 & 8.64 & 8.39 & 9.06 & 0.212 & 0.062 \\
\hline Haugh unit & $72.69^{\mathrm{b}}$ & $79.60^{\mathrm{a}}$ & $77.51^{\mathrm{ab}}$ & $80.16^{\mathrm{a}}$ & $80.93^{\mathrm{a}}$ & 0.977 & $0.048^{*}$ \\
\hline Shell thickness & 0.189 & 0.192 & 0.187 & 0.192 & 0.181 & 0.002 & 0.473 \\
\hline Shell weight & 1.74 & 1.79 & 1.78 & 1.76 & 1.83 & 0.023 & 0.801 \\
\hline
\end{tabular}

$a, b, c:$ The difference between average values carrying different letters in the same order is statistically significant. (*): $P<0.05$, (**): $P<0.01$ 
Table 8 . Third measurement internal and external quality characteristic of eggs $\left(6^{\text {th }}\right.$ week $)$

\begin{tabular}{|c|c|c|c|c|c|c|c|}
\hline \multicolumn{8}{|c|}{ GROUPS } \\
\hline & $\mathrm{C}$ & BPP1 & BPP5 & BPP10 & BPP20 & SEM & SG \\
\hline Egg weight & 12.42 & 13.13 & 12.65 & 12.98 & 12.32 & 0.11 & 0.072 \\
\hline Yolk color value & $7.80^{\mathrm{b}}$ & $9.50^{\mathrm{a}}$ & $9.80^{\mathrm{a}}$ & $10.10^{\mathrm{a}}$ & $10.40^{\mathrm{a}}$ & 0.96 & $0.001 * *$ \\
\hline Shape index & 75.53 & 77.31 & 77.96 & 78.13 & 78.49 & 0.46 & 0.259 \\
\hline Yolk index & 45.50 & 46.50 & 46.59 & 45.27 & 46.69 & 0.34 & 0.571 \\
\hline White index & 7.15 & 7.18 & 7.89 & 7.80 & 6.95 & 0.18 & 0.337 \\
\hline Haugh unit & 72.11 & 73.21 & 76.15 & 75.74 & 72.83 & 0.72 & 0.277 \\
\hline Shell thickness & $0.181^{\mathrm{c}}$ & $0.196^{\mathrm{a}}$ & $0.190^{\mathrm{ab}}$ & $0.184^{\mathrm{bc}}$ & $0.188^{\mathrm{abc}}$ & 0.00 & $0.003 * *$ \\
\hline Shell weight & 1.84 & 1.92 & 1.89 & 1.85 & 1.86 & 0.02 & 0.813 \\
\hline
\end{tabular}

$a, b, c:$ The difference between average values carrying different letters in the same order is statistically significant. (*): $P<0.05$, (**): $P<0.01$

\section{Discussion and Conclusions}

In this study, the control and pollen groups showed no statistically significant differences in the LG and feed conversion ratio, and these results were similar to those of a previous study in which the propolis ethanol extract and pollen were added to the Japanese quail rations. In this study, the LG and FCR values of group $\mathrm{C}$ showed no statistically significant differences $(\mathrm{P}>0.05)$, and therefore, these results were found to support our study (Canoğulları et al., 2009). In other studies on broilers and Japanese quails, LG and FCR values were reported to be statistically significant, and these results were not in agreement with our study $(\mathrm{P}<0.05$ and $\mathrm{P}<0.01)$ ( Seven et al., 2011; Attia et al., 2014; Babaei et al., 2016). The emergence of such differences with our might be attributed to the age and origin of the animals used and the area and content of the pollen collected, etc.

As a result of the studies on quails, it was reported that an average-sized quail egg weighed between 9.00 and $13.00 \mathrm{~g}$ (Garip and İnal, 2013). In this study, although no statistically significant difference was observed between the groups in terms of average egg weight throughout the experiment, BPP addition at different ratios showed a favorable effect on the egg weight of the quails in the control group. The pigments xanthophylls and carotenoids provide yellow color which is one of the internal quality characteristics of eggs, and the natural and synthetic products are currently used for coloring eggs. Bee pollen can be evaluated as a good natural coloring agent because it contains carotenoids in its structure. The yellow color of eggs is an important criterion for their marketing, and it has been reported that the RCF (DSM) value generally preferred by consumers is 10 (Gürbüz et al., 2003).

At the end of the trial, the desired RCF values were obtained, and these values were found to be higher in the BPP-supplemented groups compared to the control group. At the first measurement (at the end of the $2^{\text {nd }}$ week of the experiment), higher numerical RCF values were found in the BPPsupplemented groups compared to the control group. The reason for this was that the coloring effect provided by the feeds begins from after the $2^{\text {nd }}$ day, and then, contiunes rising, reaching its highest levels after the $9^{\text {th }}-12^{\text {th }}$ days, as explained by (Kirkpinar and Erkek, 1999). The RCF values obtained at the $2^{\text {nd }}$ measurement (at the end of week $4^{\text {th }}$ ) were statistically significant in all BPP groups (P $<0.01$ ), with the highest values obtained at the end of the experiment (at the end of week $6^{\text {th }}$ ) $(\quad(\mathrm{P}<0.01)$. At the end of the experiment, it was found that the addition of BPP at different concentrations to quail rations- positively affected the RCF values; an increase in the RCF values was directly proportional to an increase in the concentration of BPP. 
No significant differences were observed in shape index between different groups at the end of this sixweek trial. The shape index values obtained for the Japanese quails in this study were similar to those (79.54\%) mentioned in a previous study performed to determine some internal and external quality characteristics of the quail eggs (Özçelik, 2002). During the experimental period it was found that the BBP-supplemented groups showed statistically higher yolk index values $(\mathrm{P}<0.05)$, in the first measurement, but no significant differences were observed in the other two measurements. Although the yolk index values obtained in the last measurement were different from the initial measurement results, they were found to be similar to those obtained in a previous study conducted to investigate the effect of selection for live weight on the reproductive performance of Japanese quails (45.01) (Türkmut et al., 1999). The white index values, which are an important egg quality criterion, did not show any significant difference between groups, and it was observed that the BPP-supplemented groups generally showed higher white index values. These values, differed with a study conducted on Japanese quails (11.43) (Özçelik, 2002).

While significant differences in the Haugh unit values were obtained between the groups in the first $(\mathrm{P}<0.01)$ and second $(\mathrm{P}<0.05)$ measurements, no significant difference was observed between the groups in the final measurement $(\mathrm{P}>0.05)$. The Haugh unit values ranged between 72.11 and 76.15 on average at the end of the trial, and these values lied between the value (88.930) obtained in study conducted to determine some yield and egg quality characteristics in Japanese quails and the value (68.479) obtained in a study conducted on egg quality and characteristics in Japanese quails (Altinel et al., 1996; Nazligül et al., 2001). Previous studies suggested that an ideal shell thickness should be at least $0.33 \mathrm{~mm}$ in order to be resistant to breakage, but it has been emphasized that this value should range between 0.16- and $0.23 \mathrm{~mm}$ in quail (Rahn and Paganelli, 1989, Soliman et al., 1994; Şenköylü, 2001).

In the present study, the egg shell thickness was observed to lie between the indicated values. No remarkable difference was observed between the first and second measurements of the BPPsupplemented groups with respect to the control group, and a statistically significant difference was obtained in the third measurement $(\mathrm{P}<0.01)$. At the end of the trial, the average shell thickness was found to lie between 0.181 and $0.196 \mathrm{~mm}$; these values were similar to the values reported in a study on egg quality characteristics in Japanese quails $(0.189)$, but were found to be different from the value (0.214) reported in study conducted to determine the effects of different light sources on some production traits and phenotypic correlations among some production traits and egg quality characteristics in Japanese quails (Altınel et al., 1996; Fidan, 2005). It has been reported that the shell that protects the egg by creating an outer layer constitutes approximately $11-12 \%$ of the egg weight, and the average shell weight of the standard quail egg is approximately 1-1.2 g (Altınel et al., 1996). In terms of the shell weight values, no significant difference was observed among the three measurements, and the values were comparable to each other, but were relatively high in the BPP-supplemented groups. ( $\mathrm{P}>0.05)$. In the BPP-supplemented groups, shell weight was found to be higher than control group probably because the bee pollen contains certain important minerals, such as calcium, potassium and phosphorus. Based on the the results obtained in this six-week study, we recommend BPP supplementation of the Japanese quail diet, different concentrations of BPP could be used in quail rations because it has an enhancement effect on certain egg quality characteristics, such as natural coloring, shell thickness, and it was thought that it could also be used in other poultry in future studies.

\section{Acknowledgements}

We thank the University of Usak Scientific Research Projects Coordination Unit (USRP) for the financial support of Project 2017 / TP-030.

Statement of conflict of interest

We declare no conflicts of interest in this study.

\section{References}

Altınel, A.; Güneş, H.; Kırmızıbayrak, T.; Çörekçi, Ş. G. and Bilal, T. 1996. The studies on egg quality characteristics of Japanese quails. Journal of the Faculty of Veterinary Medicine. İstanbul University. 22 (1):203-213.

Anonim, 2002. Yem katkıları ve premikslerin üretimi, ithalatı, ihracatı, satışı ve kullanımı hakkında tebliğ. Tarım ve Köyişleri Bakanlığından. Resmi Gazete. Sayı: 24967. Tebliğ No: 2002/66.

31 I P a g e

www.iiste.org 
Anonymous, 2003. EU prohibits antibiotics as growth promoters. Feed Tech. 7(7):6.

Anonim, 2005. Karma yemlere katılması ve hayvanlara yedirilmesi yasak olan maddeler hakkında tebliğ. Tarım ve Köyişleri Bakanlığından. Resmi Gazete Sayı: 25847 Tebliğ No: 2005/24.

Anonim, 2006. Yem katkıları ve premikslerin üretimi, ithalatı, ihracatı, satışı ve kullanımı hakkında tebliğde değişiklik yapılmasına dair tebliğ. Tarım ve Köyişleri Bakanlığından. Resmi Gazete. Sayı: 26056 Tebliğ No: 2006/1.

Attia, Y. A.; AbdAl-Hamid, A. E.; Ibrahim, M. S.; $\quad$ Al-Harthi, M. A.; Bovera, F. $\quad$ and Sh.Elnaggar, A. 2014. Productive performance, biochemical and hematological traits of broiler chickens supplemented with propolis, bee pollen, and mannan oligosaccharides continuously or intermittently. Livestock Science. 164:87-95.

Ball, A. 2000. The new source in poultry feeding after the ban of growth promoters. p.87-93. 5th International Feed Congress and Exhibition. Antalya.

Bach Knudsen, K. E. 2001. Development of antibiotic resistance and options to replace antimicrobials in animal diets. Proceedings of the Nutrition Society. 60:291-299.

Basim E.; Basim, H. and Özcan, M. 2006. Antibacterial activities of turkish pollen and propolis extracts against plant bacterial pathogens. Journal of Food Engineering. 77:992-996.

Babaei, S.; Rahimi, S.; Torshizi, M. A. K.; Tahmasebi, G. and Miran, S. N. K. 2016. Effects of propolis, royal jelly, honey and bee pollen on growth performance and immune system of Japanese quails. Veterinary Forum. 7(1):13-20.

Canoğulları, S.; Baylan, M.; Şahinler, N. and Şahin, A. 2009. Effects of propolis and pollen supplementations on growth performance and body components of Japanese quails (Coturnix coturnix japonica). European Poultry Science. Archiv für Geflügelkunde. 73(3):173-178.

Çakmak, İ. 2001. Apiterapi (Polen). Uludağ Arıcılık Dergisi. 1(3):38-39.

Doğaroğlu, M. 2008. Modern Beekeeping Techniques. Tekirdağ, Turkey.

Düzgüneş, O.; Kesici, T.; Kavuncu, O. and Gürbüz, F. 1987. Araştırma ve Deneme Metotları (İstatistik Metodları II). Ankara.

Fidan, E. D. 2005. The effects of different light sources on the Japanese quails (Coturnix coturnix japonica) some production traits and phenotypic correlation among some production traits and egg quality characteristics. Thesis (M.Sc.). Adnan Menderes University, Aydın, Turkey.

Garip, M. and İnal, Ş. 2013. Bıldırcın Yetiştiriciliği. YUM-BİR Yumurta Haber Bülteni. 13:10-11.

Genç, F. 1993. Arıcılığın Temel Esasları. Atatürk Üniversitesi. Ziraat Fakültesi Ofset Tesisi. Erzurum.

Güçlü, B. K. 2003. The effect of mannan oligosaccharide (Bio-mos) using on nutrition of quails performance and quality of carcass, p: 300-302. 2nd National Nutrition Congress. Konya.

Güler, T.; Ertaş, O. N.; Çiftçi M. and Dalkılıç, B. 2005. The effect of coriander seed (Coriandrum sativum L.) as diet ingredient on the performance of Japanese quail. South African Journal of Animal Science. 35(4): 261-267. 
Gürbüz, Y.; Yaşar, S. and Karaman, M. 2003. Effects of addition of the red pepper from $4^{\text {th }}$ harvest to corn or wheat based diets on egg-yolk colour and egg production in laying hens. International Journal of Poultry Science. 2(2):107-111.

Islam, K. M. S.; Schumacher, A.; and Groop, J. M. 2005. Humic acid substances in animal agriculture. Pakistan Journal of Nutrition. 4(3):126-134.

Jensen, B. B. 1998. The impact of feed additives on the microbial ecology of the gut in young pigs. Journal of Animal and Feed Science. 7:45-64.

Karataş, F. and Şerbetçi, Z. 2008. The investigation on the amounts adrenaline and noradrenaline in bee pollens. Journal of Science and Engineering, Frrat University. 20(3):419-422.

Kırkpınar, F. and Erkek, R. 1999. The effects of some natural and synthetic pigment materials on egg yolk pigmentation and production in white corn and wheat based diets. Turkish Journal of Veterinary and Animal Sciences. 23:9-14.

Medeiros, K. C. P.; Figueiredo, C. A. V.; Figueredo, T. B.; Freire K. R. L.; Santosd F. A. R.; Alcantara Neves, N. M.; Silvaa, T. M. S. and Piuvezama, M. R. 2008. Anti-allergic effect of bee pollen phenolic extract and myricetin in ovalbumin-sensitized mice. Journal of Ethnopharmacology. 119:41-46.

Nollet, L. 2005. EU close to a future without antibiotic growth promoters. World Poultry. 21(6):1415 .

Nazlıgül, A.; Türkyılmaz K. and Bardakçıŏlu, H. E. 2001. A study on some production traits and egg quality characteristics of Japanese quail. Turkish Journal of Veterinary and Animal Sciences. 25:1007-1013.

NRC, 2001. Nutrient requirements of dairy cattle. Seventh revised edition. National Academy Press. Washington, D. C.

Orzaez Villanueva, M. T.; Diaz Marquina, A.; Bravo Serrano, R. and Blazquez Abellan, G. 2002. The importance of bee-collected pollen in the diet: a study of its composition. International Journal of Food Sciences and Nutrition. 53(3):217-224.

Özçelik, M. 2002. The phenotypic correlations among some external and internal quality characteristics in Japanese quail eggs. Veterinary Journal of Ankara University. 49: 67-72.

Özen, N.; Kırkpınar, F.; Özdoğan, M.; Ertürk, M. M. and Yurtman, İ. Y. 2005. Hayvan Besleme. p.753-771. TMMOB Ziraat Mühendisleri Odası Türkiye Ziraat Mühendisliği 4th Teknik Kongresi. Ankara

Rahn, H. and Paganelli, C. V. 1989. Shell mass, thickness and density of avian eggs derived from the tables of Schönwetter. Journal of Ornithology. 130:59-68.

Schmidt, J. O. 1997. Bee product chemical composition and application. p.15. International Conference on Bee Product Properties, Applications and Apitherapy, Israel.

Seven, İ; Tatlı Seven, P.; Sur Aslan, A. and Yıldı, N. 2011. The effects of dietary bee pollen on performance and some blood parameters in Japanese quails (Coturnix coturnix japonica) breeding under different stocking densities. Journal of Faculty of Veterinary Medicine. Erciyes University. 8(3):173-180. 
Soliman, F. N. K.; Rizk, R. E. and Brake, J. 1994. Relationship between shell porosity, shell thickness, egg weight loss, and embryonic development in Japanese quail eggs. Poultry Science.73:1607-1611.

Sorkun, K. 1987. Arı Ürünleri. Bilim veTeknik Dergisi. 20:20-2.

Sönmez, R. and Altan, Ö. 1992. Teknik Arıcılık. p.246. Ege Üniversitesi Ziraat Fakültesi Yayınları. İzmir.

Stanley, R. G. and Linskens, H. F. 1985. Pollen biologie, biochemie gewinnung und verwendung. Urs freund verlag greifenberg-ammersee.

Şenköylü, N. 2001. Modern Tavuk Üretimi ～Kitabı. TrakyaÜniversitesi Basımevi. Tekirdağ.

Türkmut, L.; Altan, Ö.; Oğuz, İ. and Yalçın, S. 1999. Effects of selection for four week body weight on reproductive performance in Japanese quail. Turkish Journal of Veterinary and Animal Sciences. 23:229-234.

Yalçın, S.; Kocaoğlu Güçlü, B.; Karakaş Oğuz, F., and Yalçın, S. 2002. The usage of enzymic, probiotic and antibiotic in laying hen rations. Veterinary Journal of Ankara University. 49:135141. 